\title{
MODEL PEMBELAJARAN BERBASIS PROYEK PADA MATA KULIAH MEDIA PEMBELAJARAN
}

\author{
Fajar Adinugraha \\ Prodi Pendidikan Biologi, Universitas Kristen Indonesia \\ Email: fajar.adinugraha@uki.ac.id
}

\begin{abstract}
Abstrak
Tujuan penelitian ini untuk menjelaskan bentuk kegiatan mata kuliah Media Pembelajaran dengan model Pembelajaran Berbasis Proyek. Selain itu, untuk mengetahui gambaran persepsi mahasiswa terhadap model Pembelajaran Berbasis Proyek pada mata kuliah Media Pembelajaran. Penelitian ini juga bertujuan untuk mengetahui gambaran tanggapan mahasiswa terhadap kemampuan dosen mengajar menggunakan model Pembelajaran Berbasis Proyek. Jenis penelitian ini merupakan penelitian deskriptif kuantitatif yang menggunakan metode studi pustaka dan survey. Salah satu bentuk kegiatan mata kuliah Media Pembelajaran dengan model Pembelajaran Berbasis Proyek adalah pembuatan media video tutorial dengan tahapan: 1) pembuatan power point interaktif mengggunakan aplikasi Microsoft Office Power Point; 2) pembuatan flash menggunakan aplikasi iSpring free 7; 3) pembuatan video tutorial menggunakan aplikasi Screecast-O-Matic; dan 4) publikasi melalui media sosial Youtube. Persepsi mahasiswa terhadap model Pembelajaran Berbasis Proyek pada mata kuliah Media Pembelajaran adalah pada kategori baik (sangat baik $30 \%$ dan baik $70 \%$ ). Selanjutnya, tanggapan mahasiswa terhadap kemampuan dosen mengajar menggunakan model Pembelajaran Berbasis Proyek adalah pada kategori baik (sangat baik 50\% dan baik 50\%).

Kata Kunci : Pembelajaran Berbasis Proyek, persepsi mahasiswa, media pembelajaran
\end{abstract}

\begin{abstract}
The purpose of this research is to explain the forms of Learning Media subject with a Project-Based Learning models. In addition, to find out the description of student's perception in the Project-Based Learning model in the Learning Media subject. The research also aims to find out student's response to the lecturer's teaching skill at using the Project-Based Learning model. It is a quantitative descriptive research that uses literature study and survey methods. One of Learning Media subject activities with the Project-Based Learning model is the creation of video tutorials with stages: 1) creating interactive power points using Microsoft Office Power Point application; 2) creating flash using iSpring free 7 application; 3) making a video tutorial using the Screecast-O-Matic application; and 4) making publication through social media Youtube. Student's perception in the Project-Based Learning model in Learning Media subject is in the good category (very good 30\% and good 70\%). Next, student's response to the lecturer's teaching skill at using the Project-Based Learning model is also in the good category (very good $50 \%$ and good $50 \%$ ).
\end{abstract}

Keywords: Project-Based Learning, student's perception, learning medium

\section{PENDAHULUAN}

Program Studi Pendidikan Biologi Universitas Kristen Indonesia memiliki tujuan untuk menyiapkan lulusan yang mampu berdaya saing sebagai guru biologi di SMP maupun SMA. Salah satu mata kuliah yang mendukung tercapainya tujuan tersebut adalah mata kuliah Media
Pembelajaran. Mahasiswa Program Studi Pendidikan Biologi diharapkan mempunyai gambaran, pemahaman, keterampilan, dan kemampuan mengenai media pembelajaran yang sesuai dan dapat diterapkan di kelas. Media pembelajaran yang dimaksud adalah media pembelajaran yang bersifat tradisional maupun modern (IT). Oleh 
karena itu, setelah menempuh mata kuliah ini para mahasiswa diharapkan mampu menguasai berbagai macam media pembelajaran untuk mendukung pembelajaran ketika kelak menjadi guru. Mahasiswa dapat memilih media yang sesuai dengan kondisi siswa dan fasilitas sekolah.

Pelaksanaan perkuliahan atau pembelajaran mata kuliah Media Pembelajaran ini menggunakan model Pembelajaran Berbasis Proyek (Project Based Learning). Hal ini sesuai dengan tujuan perkuliahan yaitu menghasilkan mahasiswa yang mampu menciptakan media pembelajaran untuk menunjang kegiatan pembelajaran biologi di sekolah.

Referensi [1] mengatakan bahwa model Pembelajaran Berbasis Proyek memiliki kelebihan antara lain: 1) meningkatkan hasil belajar dan motivasi siswa, 2) mendorong siswa untuk kreatif dan mandiri menghasilkan produk, 3) memberikan pengalaman siswa untuk membangun pengetahuannya sendiri, 4) meningkatkan kemampuan siswa untuk mengkomunikasikan produk. Model pembelajaran berbasis proyek dapat meningkatkan kemampuan pemecahan masalah dan kecerdasan emosional [2]. Selanjutnya, dalam penelitian [3] mengatakan bahwa model pembelajaran berbasis proyek dapat meningkatkan keterampilan proses sains siswa seperti: observasi, klasifikasi, interpretasi, prediksi, berkomunikasi, merencanakan percobaan, menerapkan konsep, berhipotesis, dan mengajukan pertanyaan.

Kelebihan dari model Pembelajaran Berbasis Proyek ini sesuai dengan Kurikulum yang dijalankan di Perguruan Tinggi yaitu Kurikulum Berbasis Kompetensi yang mengacu pada KKNI.
Referensi [4], Kerangka Kualifikasi Nasional Indonesia (KKNI) bidang pendidikan tinggi merupakan kerangka penjenjangan kualifikasi yang dapat menyandingkan, menyetarakan, dan mengintegrasikan capaian pembelajaran dari jalur pendidikan nonformal, pendidikan informal, dan/atau pengalaman kerja ke dalam jenis dan jenjang pendidikan tinggi.

Sebuah kurikulum akan tergambar jelas dalam proses pelaksanaan pembelajarannya. Dalam meningkatkan kualitas lulusan perguruan tinggi, salah satu rambu-rambu yang harus dipenuhi di tiap jenjang dalam proses pembelajaran adalah pembelajaran yang berpusat pada mahasiswa (Student Centered Learning) dan asesmen autentik [5]. Hal ini selaras dengan Model Pembelajaran Berbasis Proyek yang lebih menekan pembelajaran berpusat pada siswa (Student Centered Learning) dan asesmen autentik.

Pembelajaran berpusat siswa (SCL) merupakan strategi pembelajaran yang menempatkan siswa (mahasiswa) sebagai siswa yang aktif. Aktif dalam hal ini adalah aktif secara keterampilan (psikomotorik), bersikap (afektif) dan berpikir (kognitif). Hal ini senada dengan [6] yang mengatakan bahwa Student Centered Learning memiliki prinsip pembelajaran aktif, pembelajaran interaktif, pembelajarn mandiri, pembelajaran kolaboratif, pembelajaran kooperatif, pembelajarn kontekstual, dan penilaian hasil belajar mahasiswa. Menurut penelitian [7], kreativitas mahasiswa yang mengikuti strategi pembelajaran berpusat pada siswa lebih tinggi daripada mahasiswa yang mengikuti strategi pembelajaran langsung dengan rerata skor kreativitas mahasiswa yang mengikuti 
perkuliahan dengan strategi pembelajaran berpusat pada siswa lebih tinggi daripada strategi pembelajaran langsung.

Selain pembelajaran berpusat pada siswa, salah satu prinsip model Pembelajaran Berbasis Proyek adalah asesemen autentik. Referensi [8], asesmen autentik merpakan penilaian yang menilai dari kesiapan (perencanaan), proses, dan hasil belajar secar utuh dimana penilaian ini sesuai dengan pembelajaran biologi yang menekankan pad proses sains. Melalui asesmen autentik akan membuat pembelajaran menjadi bermakna karena tidak hanya menilai dari segi pengetahuan (kognitif) saja melainkan segi keterampilan (psikomotorik) dan segi sikap (afektif).

Oleh karena itu, artikel ini bertujuan untuk 1) mengetahui deskripsi pembelajaran media pembelajaran dengan model Pembelajarn Berbasis Proyek, 2) mengetahui gambaran persepsi mahasiswa terhadap model Pembelajaran Berbasis Proyek pada mata kuliah Media Pembelajaran, dan 3) mengetahui gambaran tanggapan mahasiswa terhadap kemampuan dosen mengajar menggunakan model Pembelajaran Berbasis Proyek.

\section{METODE}

\section{Metode}

Metode penelitian dalam penelitian ini adalah deskriptif kuantitatif. Jenis penelitian ini merupakan penelitian deskriptif kuantitatif yang menggunakan metode studi pustaka dan survey. Penelitian deskriptif adalah penelitian yang dilakukan untuk mengetahui nilai variabel mandiri, baik satu variabel atau lebih (independent) tanpa membuat perbandingan, atau penghubungan dengan variabel yang lain [9]. Penelitian dilakukan di bulan Februari - Juni 2018 pada semester genap tahun ajaran 2017/2018.

\section{Populasi dan sampel}

Populasi dalam penelitian ini adalah 63 mahasiswa program studi Pendidikan Biologi, Universitas Kristen Indonesia. Teknik pengambilan sampel dalam penelitian ini adalah non probability sampling dengan teknik sampling purposive. Sampling puposive, adalah teknik menentukan sampel dengan pertimbangan tertentu sesuai dengan tujuan yang dikehendaki.

Sampel yang digunakan adalah 10 mahasiswa rombongan belajar (rombel) mata kuliah Media Pembelajaran pada semester genap 2017/2018.

\section{Teknik pengumpulan dan analisis data}

1. Data deskripsi bentuk model pembelajaran berbasis proyek.

Pengambilan data ini melalui observasi selama kegiatan pembelajaran berlangsung yang dilaksanakan dari bulan Februari - Juni 2018. Data berupa jenis kegiatan yang sudah dilakukan yang menggunakan tahapan model pembelajaran berbasis proyek.

2. Data persepsi mahasiswa terhadap model pembelajaran berbasis proyek pada mata kuliah media pembelajaran.

Data diperoleh dengan memberikan kuesioner kepada mahasiswa peserta mata kuliah media pembelajaran secara daring di http://gg.gg/angketmedia. Pengisian kuesioner dilakukan pada tanggal $25 \mathrm{Mei}$ hingga 20 Juni 2018. Kuesioner ini memuat 7 (tujuh) indikator dengan 30 butir pertanyaan yang disajikan pada tabel 1. Data kemudian ditabulasi dan dianalisis menggunakan kriteria sebagai berikut.

Kriteria: 


$$
\begin{aligned}
& 130 \leq X \leq 150=\text { sangat baik } \\
& 105 \leq X \leq 129=\text { baik } \\
& 80 \leq X \leq 104=\text { cukup } \\
& 55 \leq X \leq 79=\text { kurang } \\
& 30 \leq X \leq 54=\text { buruk }
\end{aligned}
$$

Tabel 1. Indikator pertanyaan kuesioner model Pembelajaran Berbasis Proyek pada mata kuliah Media Pembelajaran

\begin{tabular}{llc}
\hline No & Indikator & $\begin{array}{c}\text { Jumlah } \\
\text { pertanyaan }\end{array}$ \\
\hline 1. & Interaksi siswa dan dosen & 5 \\
2. & Minat belajar mahasiswa & 4 \\
3. & $\begin{array}{l}\text { Kompetensi memahami } \\
\text { materi ajar }\end{array}$ & 5 \\
4. & $\begin{array}{l}\text { Kompetensi berpikir kritis, } \\
\text { efektif, dan efisien }\end{array}$ & 5 \\
5. & Kompetensi manajemen \\
waktu & 3 \\
6. & $\begin{array}{l}\text { Hasil belajar siswa } \\
\text { 7. }\end{array}$ & 5 \\
& $\begin{array}{l}\text { mosesuaian penerapan pembelajarn dengan } \\
\text { karakteristik mata kuliah }\end{array}$ & 3 \\
\hline & & \\
\hline
\end{tabular}

Selain dilihat secara keseluruhan, data juga dianalisis per indikator untuk melihat persepsi mahasiswa terhadap proses pembelajaran dengan model Pembelajaran Berbasis Proyek per indikator.

\section{Data persepsi mahasiswa terhadap kemampuan mengajar dosen menggunakan model Pembelajaran Berbasis Proyek.}

Data diperoleh dengan pengisian kuesioner secara daring di alamat http://gg.gg/angketmedia. Kuesioner berisi 15 butir pertanyaan. Kuesioner ini bertujuan untuk melihat persepsi mahasiswa terhadp kemampuan mengajar dosen menggunakan model Pembelajaran Berbasis Proyek. Data kemudian ditabulasi dan dianalisis menggunakan kriteria sebagai berikut.

Kriteria

$$
\begin{array}{ll}
63 \leq X \leq 75 & =\text { sangat baik } \\
51 \leq X \leq 62 & =\text { baik } \\
39 \leq X \leq 50 & =\text { cukup } \\
27 \leq X \leq 38 & =\text { kurang } \\
15 \leq X \leq 26 & =\text { buruk }
\end{array}
$$

\section{HASIL DAN PEMBAHASAN}

Media Pembelajaran merupakan salah satu mata kuliah pilihan pada program Studi Pendidikan Biologi UKI. Perkuliahan berlangsung selama 16 pertemuan dengan jumlah 2 sks tiap pertemuan. Namun, pada pelaksanaannya dosen dan mahasiswa mengadakan konsultasi di luar jam kuliah untuk mendiskusikan proyek tiap mahasiswa. Di akhir perkuliahan, diharapkan mahasiswa mampu membuat media pembelajaran yang sesuai diterapkan di sekolah. Tidak semua jenis media pembelajaran efektif diterapkan di kelas tertentu. Oleh karena itu, mahasiswa diajak untuk selektif dalam memilih media pembelajaran. Berikut akan dibahas bentuk model Pembelajaran Berbasis Proyek pada mata kuliah Media Pembelajaran.

\section{Deskripsi bentuk model pembelajaran berbasis proyek}

Sebagai sebuah model pembelajaran, model pembelajaran berbasis proyek (PBP) memiliki sintak. Sintak merupakan tahapan-tahapan dalam model pembelajaran. Gambar tahapan Model Pembelajaran Berbasis Proyek disajikan dalam gambar 1 [10].

Proyek yang digunakan dalam matakuliah ini adalah proyek media pembelajaran berbasis daring (online) dan proyek media pembelajaran konvensional (media game indoor dan outdoor). Proyek ini dilaksanakan sebanyak 3 (tiga) kali. Jadi, dilakukan evaluasi atau monitoring hasil produk setiap 5 pertemuan sekali dari 16 
kali pertemuan. Berikut dijelaskan salah satu tahapan proyek pembuatan media

pembelajaran berbasis daring.

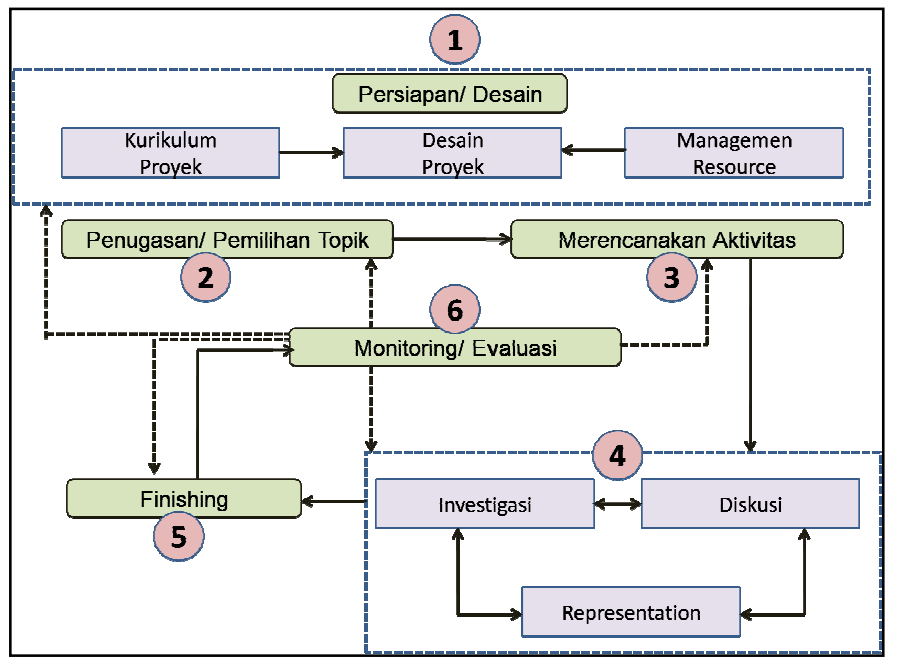

Sumber: (Hutasuhut, 2010:201)

Gambar 1 Diagram tahapan dalam Model Pembelajaran Berbasis Proyek

Tahap 1 yaitu persiapan, dosen dan mahasiswa menentukan masalah dalam hal ini adalah media pembelajaran yang mudah dibuat dalam waktu singkat tetapi dapat dirasakan manfaatnya bagi siswa dalam kelas maupun siswa di luar kelas. Akhirnya, dibuatlah media pembelajaran video tutorial dengan 1) menggabungkan media power point interaktif; 2) flash menggunakan program iSpring free $7 ; 3$ ) video tutorial menggunakan Screecast-OMatic; dan 4) publikasi melalui media sosial Youtube.

Tahap 2 yaitu penugasan/ pemilihan topik, dosen membebaskan mahasiswa untuk memilih topik atau materi yang akan digunakan dalam pembuata proyek. Materi harus berhubungan dengan pelajaran Biologi.

Tahap 3 yaitu merencanakan aktivitas, mahasiswa membuat rencana pembuatan proyek. Tahap 4 yaitu diskusi, investigasi masalah, dan representation. Selanjutnya dilakukan tahap 5 yaitu finishing atau pembuatan proyek. Kemudian pada tahap terakhir yaitu tahap monitoring atau evaluasi terhadap hasil produk.

Proyek video tutorial pembelajaran dipilih karena sebagai calon guru abad 21, mahasiswa perlu menguasai kemampuan teknologi informasi. Proyek yang dipilih menggunakan aplikasi yang sederhana sehingga mahasiswa tidak membutuhkan waktu lama dalam membuat proyek ini. Tahapan pembuatan proyek video tutorial pembelajaran sebagai berikut (gambar 2).

1. Power point interaktif mengggunakan program Microsoft Office Power Point.

2. Flash menggunakan aplikasi iSpring free 7.

3. Video tutorial menggunakan aplikasi Screecast-O-Matic.

4. Publikasi melalui media sosial Youtube.

Guru menghadapi generasi digital yang terus berkembang. Pembelajaran abad 21 
merupakan pembelajaran dengan akses kemudahan informasi. Oleh karena itu, media pembelajaran video tutorial ini diharapkan menjadi salah satu cara untuk membuat akses informasi pembelajaran menjadi cepat dan mudah diakses. Dengan pembuatan yang sederhana tapi bisa diterima oleh siswa. Referensi [11], fenomena ini tidak bisa dihindari oleh seorang guru. Guru mungkin akan kehilangan eksistensinya jika tidak mampu merubah diri, tetapi guru justru akan mendapat banyak peluang jika mampu meningkatkan profesionalitasnya dan mampu berinovasi dengan teknologi.

Meskipun demikian tidak semua media pembelajaran harus berbasis teknologi dan informasi. Media pembelajaran bukan berarti menggantikan posisi guru sebagai fasilitator dan motivator. Media pembelajaran berfungsi sebagai sarana untuk mempermudah pembelajaran. Sebagai calon guru dan guru perlu

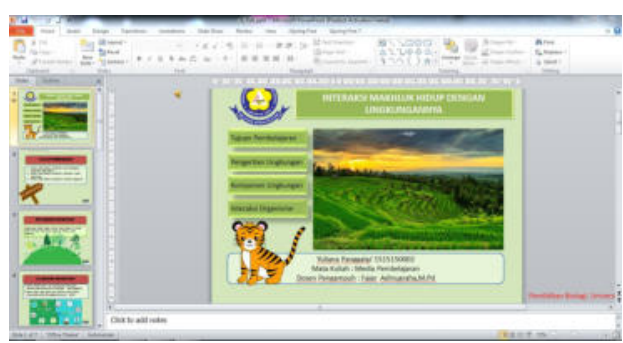

(a)

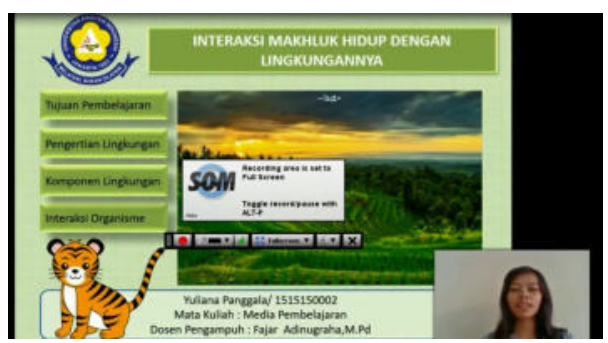

(c) menyadari akan hal ini. Terkadang guru terlalu sibuk waktunya dihabiskan untuk membuat media pembelajaran tetapi tidak memperhatikan tugas-tugas pokok lain sebagai seorang guru. Oleh karena itu,guru perlu bijaksana dalam membuat media pembelajaran.

Pada perkuliahan media pembelajaran ini memang diajak untuk membuat media yang mudah dan tidak memakan waktu yang lama. Selain proyek video tutorial pembelajaran, mahasiswa juga membuat proyek komik pembelajaran dan proyek media permainan indoor-outdoor.

2. Persepsi mahasiswa terhadap model pembelajaran berbasis proyek pada mata kuliah media pembelajaran

Berdasarkan data yang diperoleh dari hasil kuesioner, kemudian ditabulasi dan dideskripsikan. Hasil persepsi mahasiswa berada pada rentang $4,00-4,48$ per indikator dari skala $1,00-5,00$.

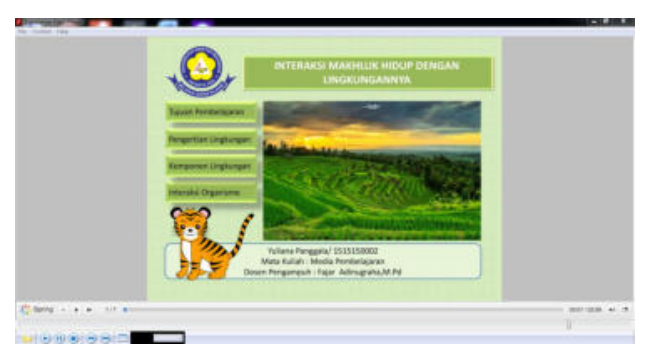

(b)

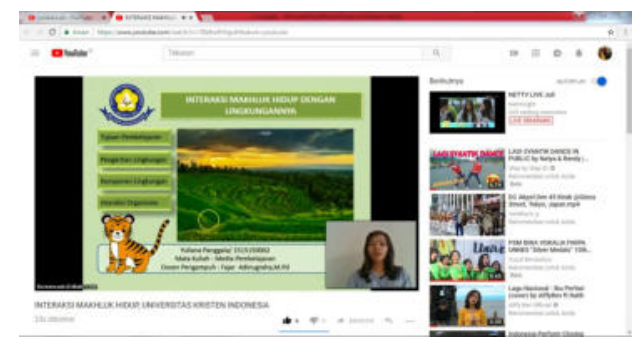

(d)

Gambar 2 Tahapan proses pembuatan video tutorial pembelajaran (a) power point interaktif, (b) flash dengan converter iSpring free 7, (c) video tutorial dengan Screecast$O$-Matic (d) media sosial youtube sebagai publikasi video tutorial 
Hal ini berarti persepsi mahasiswa terhadap setiap indikator proses Pembelajaran Berbasis Proyek pada kriteria baik. Hasil tersebut sebagai berikut: A) interaksi siswa dan dosen $(4,20)$; B) minat belajar mahasiswa $(4,38)$; C) kompetensi memahami materi ajar $(4,14)$; D) kompetensi berpikir kritis, efektif dan efisien $(4,48)$; E) kompetensi manajemen waktu $(4,00)$; F) hasil belajar siswa (4,32); dan G) kesesuaian penarapan model pembelajaran dengan karakteristik mata kuliah (4,33). Gambar diagram persepsi mahasiswa terhadap proses pembelajaran dengan model
Pembelajaran Berbasis Proyek tiap indikator dapat dilihat pada gambar 3.

Secara keseluruhan persepsi mahasiswa terhadap model pembelajaran berada pada kategori baik (sangat baik 30\% dan baik 70\%). Mahasiswa menilai bahwa pembelajaran dengan Model Pembelajaran Berbasis Proyek menggugah pengetahuan mahasiswa dalam memilih dan membuat media pembelajaran yang sesuai untuk siswa. Gambar persepsi mahasiswa terhadap Model Pembelajaran Berbasis Proyek pada mata kuliah Media Pembelajaran dapat dilihat pada gambar 4.a.

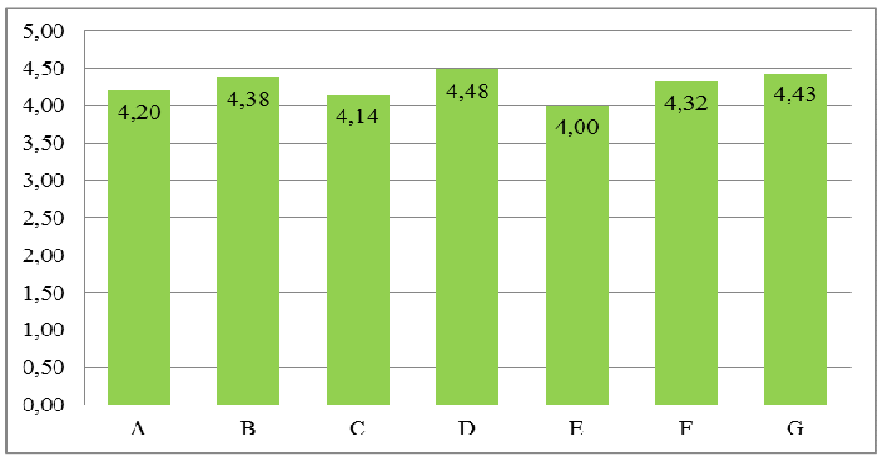

Gambar 3. Diagram persepsi mahasiswa terhadap model Pembelajaran Berbasis Proyek pada mata kuliah Media Pembelajaran per indikator
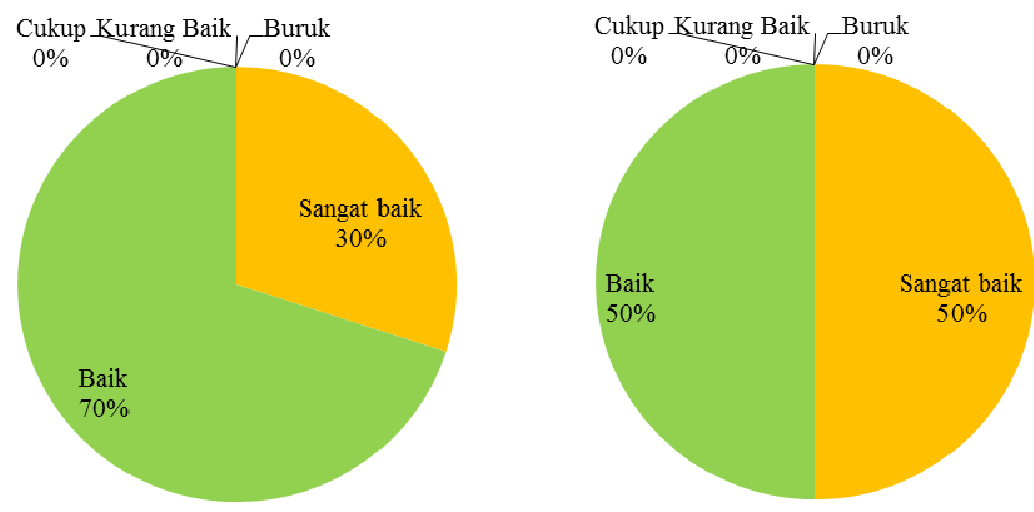

Gambar 4. Diagram a) persepsi mahasiswa terhadap model Pembelajaran Berbasis Proyek pada mata kuliah Media Pembelajaran, b) persepsi mahasiswa terhadap kemampuan mengajar dosen menggunakan model Pembelajaran Berbasis Proyek 
Referensi [12], mengatakan bahwa terdapat hubungan yang signifikan antara persepsi siswa (mahasiswa) terhadap penerapan model pembelajaran dengan prestasi belajar. Persepsi yang baik tentang penerapan sebuah model pembelajaran mempunyai hubungan terhadap prestasi belajar. Namun, perlu dilakukan pembiasan dalam pembelajaran. Oleh karena itu, di dalam pelaksanaan kuliah Media Pembelajaran menggunakan model Pembelajaran Berbasis Proyek dari pertemuan 1 hingga pertemuan 16. Hal ini dimaksudkan agar mahasiswa menjadi terbiasa dengan model tersebut.

\section{Tanggapan mahasiswa terhadap kemampuan mengajar dosen menggunakan model Pembelajaran Berbasis Proyek.}

$\begin{array}{lcr}\text { Penilaian } & \text { mahasiswa } & \text { terhadap } \\ \text { kemampuan } & \text { mengajar } & \text { dosen }\end{array}$ Berbasis Proyek adalah baik (sangat baik $50 \%$ dan baik 50\%). Data disajikan pada gambar 4.b. Mahasiswa menilai bahwa dosen sudah melakukan perencanaan pembelajaran dengan baik yaitu dengan menyampaikan kontrak perkuliahan dan perkuliahan berjalan sesuai waktu yang ditentukan. Proses pembelajaran juga mengacu pada Student Centered Learning. Hal ini dilihat dengan banyak aktivitas pembelajaran yang dilakukan mahasiswa.

Dosen bersifat memotivasi dan memfasilitasi. Bahkan dilakukan konsultasi di luar jam perkuliahan baik melalui tatap muka maupun secara daring. Referensi [13] mengatakan bahwa terdapat hubungan yang signifkan antara kemampuan mengajar dosen dengan prestasi belajar. Model atau metode pembelajaran yang sesuai dan didukung dengan kompetensi mengajar dosen akan membuat pembelajaran lebih berkualitas.

\section{SIMPULAN}

Berdasarkan hasil penelitian di atas, simpulan dalam penelitian ini adalah sebagai berikut.

1. Salah satu bentuk kegiatan mata kuliah Media Pembelajaran dengan model Pembelajaran Berbasis Proyek adalah pembuatan media video tutorial dengan tahapan: 1) pembuatan power point interaktif mengggunakan program Microsoft Office Power Point; 2) pembuatn flash menggunakan aplikasi iSpring free 7 ; 3) pembuatan video tutorial menggunakan aplikasi Screecast-OMatic; dan 4) publikasi melalui media sosial Youtube.

2. Persepsi mahasiswa terhadap model Pembelajaran Berbasis Proyek pada mata kuliah Media Pembelajaran adalah pada kategori baik (sangat baik 30\% dan baik 70\%).

3. Tanggapan mahasiswa terhadap kemampuan dosen mengajar menggunakan model Pembelajaran Berbasis Proyek adalah pada kategori baik (sangat baik 50\% dan baik 50\%).

\section{DAFTAR PUSTAKA}

[1] A. Baidowi, S. Sumarni, and A. Amirudin. "Pengaruh model pembelajaran berbasis proyek terhadap kemampuan menulis karya ilmiah geografi siswa sma". Jurnal Pendidikan Geografi, 20 (1): 48-58, 2015.

[2] N.K.D Karina, I.W. Sadia, and I.W. Suastra. "Pengaruh model pembelajaran berbasis proyek terhadap kemampuan pemecahan masalah dan kecerdasan emosional 
siswa smp". E-Journal Program Pascasarjana Universitas Pendidikan Ganesha, 4: 1-10, 2014.

[3] S. Nawawi, A. Amilda, and M.P. Sari. "Pengaruh model pembelajaran berbasis proyek terhadap keterampilan proses sains pada materi pengelolaan lingkungan". Jurnal Pena Sains, 4 (2): 88-96, 2017.

[4] Permendikbud Nomor 73 tahun 2013. "Peraturan menteri pendidikan dan kebudayaan republik indonesia tentang penerapan kerangka kualifkasi nasional indoneia bidang pendidikan tinggi”. (1-9), 2013.

[5] Fitri. "Kurikulum nasional berbasis kompetensi mengacu pada kkni”,2013. [Online]. Tersedia: http://www.kopertis12.or.id/2013/04/ 28/kurikulum-nasional-berbasiskompetensi-mengacu-padakkni.html. [Diakses 08 Juli 2018].

[6] H. Harsono. "Student-centered learning di perguruan tinggi". Jurnal Pendidikan Kedokteran dan Profesi Kesehatan Indonesia. 3 (1): 1-5), 2008.

[7] A. Ardian and S. Munadi. "Pengaruh strategi pembelajaran student centered learning dan kemampuan spasial terhadap kreativitas mahasiswa". Jurnal Pendidikan Teknologi dan Kejuruan. 22 (4): 454466, 2015.
[8] E.D. Puspitasari. "Keterlaksanaan penilaian autentik dan korelasinya dengan hasil belajar biologi sma". Proceeding Biology Education Conference. 13 (1): 196-202, 2016.

[9] Siregar S. "Statistika deskriptif untuk penelitian". Jakarta: Rajawali Press, 2013.

[10] Hutasuhut, S. "Implementasi pembelajaran berbasis proyek (Project Based Learning) untuk meningkatkan motivasi dan hasil belajar mata kuliah pengantar ekonomi pembangnan pada jurussan manjemen FE UNIMED". Jurnal Pekbis. 2(1) 196-207,2010.

[11] W. Wartomo. "Peran guru dalam pembelajaran era digital". Prosiding temu ilmiah nasional guru (TING) VIII. 265-275, 2016.

[12] E. Effendi. "Hubungan persepsi siswa terhadap penerapan model pembelajaran kooperatif tipe tutor sebaya dengan prestasi belajar fisika". Jurnal Pendidikan Fisika Universtas Muhammadiyah Metro. 3 (2):14-24,2015.

[13] E. Elianti. "Pengaruh kemampuan mengajar dosen program sutdi matematika fip unsyiah terhadap prestasi belajar mahasiswa dalam mata kuliah trigonometri". 2 (1): 3847,2013. 